\title{
KUALITAS PELAYANAN KENAIKAN PANGKAT PEGAWAI NEGERI SIPIL OLEH BADAN KEPEGAWAIAN DAERAH KABUPATEN GUNUNG MAS
}

\author{
INDAH TRI HANDAYANI \\ Dosen Program Studi IImu Administrasi Negara Fakultas IImu Sosial dan IImu Politik \\ Universitas Muhammadiyah Palangkaraya \\ Email : indahtry.it@gmail.com
}

\begin{abstract}
Good governance developments in Indonesia, further encouraging improvements in many areas of government in Indonesia. One important thing that can be done in the development of good governance is the renewal of the public service. One of the values of good governance is essential to be implemented in the public service is service quality. As with any promotion services provided by the Regional Employment Board of Gunung Mas, good service quality are the expectations of the service users are civil servants who proposed the promotion.

Research, seminars and writings of experts on service delivery promotion of civil servants are good quality and havemany. The issue of promotion services qualified civil servants are still not running as it shauld. For the research conducted at the Regional Employment Board Gunung Mas is to see how the quality of service of civil servants promotions given and what are the constraints in service promotion.

The maincore of service delivery promotion of civil servants is the timeliness quality of service, things that need to be considered here related to the waiting time and processing time, then the accuracy of service, relating to service reliability and error-free service as well as Ease of Getting Care, associated with a service, a serving officer/administrative staff, support facilities are like computers and others.
\end{abstract}

Keywords: service, quality, of promotion

\section{ABSTRAK}

Perkembangan Good governance di Indonesia, semakin mendorong perbaikan di berbagai bidang pemerintahan di Indonesia. Salah satu hal yang penting yang bisa dilakukan dalam pengembangan good governance adalah pembaharuan pelayanan publik. Salah satu nilai dari good governance yang penting untuk dilaksanakan dalam pelayanan publik adalah kualitas pelayanan. Seperti halnya pelayanan kenaikan pangkat yang diberikan oleh Badan Kepegawaian Daerah Kabupaten Gunung Mas, kualitas pelayanan yang baik merupakan harapan para pengguna jasa pelayanan yaitu para pegawai negeri sipil yang mengusulkan kenaikan pangkatnya.

Penelitian, seminar dan karya tulisan dari para ahli tentang penyelenggaraan pelayanan kenaikan pangkat pegawai negeri sipil yang baik dan berkualitas telah banyak. Persoalannya pelayanan kenaikan pangkat pegawai negeri sipil yang berkualitas tersebut masih belum dijalankan sebagaimana mestinya. Untuk itu penelitian yang dilakukan di Badan Kepegawaian Daerah Kabupaten Gunung Mas inimelihat bagaimana kualitas pelayanan kenaikan pangkat pegawai negeri sipil yang diberikan dan apa yang menjadi kendala dalam pelayanan kenaikan pangkat.

Inti utama dari penyelenggaraan pelayanan kenaikan pangkat pegawai negeri sipil adalah kualitas dari Ketepatan Waktu Pelayanan, hal-hal yang perlu diperhatikan disini terkait dengan waktu tunggu dan waktu proses, kemudian Akurasi Pelayanan, berkaitan dengan reliabilitas pelayanan dan bebas dari kesalahan pelayanan serta Kemudahan Mendapatkan Pelayanan, berkaitan dengan tempat pelayanan, petugas yang melayani/staf administrasi, fasilitas pendukung seperi komputer dan lain-lain.

Kata kunci : pelayanan, kualitas, kenaikan pangkat 


\section{PENDAHULUAN}

Undang-undang Nomor 43 Tahun 1999 tentang Pokok-pokok Kepegawaian pada pasal 3 disebutkan bahwa Pegawai Negeri berkedudukan sebagai aparatur Negara yang bertugas memberikan pelayanan kepada masyarakat secara profesional, jujur, adil dan merata dalam penyelenggaraan tugas negara, pemerintah dan pembangunan.

Badan Kepegawaian Daerah Kabupaten Gunung Massebagai lembaga yang mempunyai tugas pokok dan fungsi dalam mengelola manajemen kepegawaian, berusaha semaksimal mungkin melaksanakan tugas sebagai pemberi pelayanan di bidang kepegawaian, seperti pelayanan kenaikan pangkat. Kegiatan pelayanan Kenaikan Pangkat Pegawai Negeri Sipil pada Badan Kepegawaian Daerah Kabupaten Gunung Masmengacu pada Peraturan Pemerintah Nomor 12 tahun 2002 tentang Perubahan Atas Peraturan Pemerintah Nomor 99 tahun 2000 tentang Kenaikan Pangkat Pegawai Negeri Sipil.

Pelayanan Kenaikan Pangkat Pegawai Negeri Sipil yang diberikan oleh Badan Kepegawaian Daerah Kabupaten Gunung Mas menjadi menarik untuk diteliti, sebab pelayanan yang berkualitas khususnya pelayanan Kenaikan Pangkat sangatlah diharapkan oleh Pegawai Negeri Sipil Lingkungan Pemerintah Daerah Kabupaten Gunung Mas, karena menyangkut masa depan mereka dalam hal mendapatkan promosi jabatan dan kenaikan gaji.

Fokus penelitian ini diarahkan pada permasalahan Pelayanan Kenaikan Pangkat Pegawai Negeri Sipil yang diberikan oleh Badan Kepegawaian Daerah Kabupaten Gunung Mas pada Lingkungan Pemerintah Daerah Kabupaten
Gunung Mas khususnya kepada Pegawai Negeri Sipil Struktural yang mengusulkan kenaikan pangkat pada periode 1 April 2014.

Beranjak dari adanya persoalan dalam pelayanan kenaikan pangkat pegawai negeri sipil oleh Badan Kepegawaian Daerah Kabupaten Gunung Mas, maka rumusan masalah dalam penelitian ini adalah 1) bagaimana kualitas pelayanan kenaikan pangkat pegawai negeri sipil yang diberikan oleh Badan Kepegawaian Daerah Kabupaten Gunung Mas ?, dan 2) apa kendala yang dihadapi dalam pelayanan kenaikan pangkat pegawai negeri sipil yang diberikan oleh Badan Kepegawaian Daerah Kabupaten Gunung Mas ?.

Tujuan yang hendak dicapai dalam penelitian ini adalah untuk mendiskripsikan, menganalisa dan menginterprestasikan 1) kualitas pelayanan kenaikan pangkatpegawai negeri sipil yang diberikan oleh Badan Kepegawaian Daerah Kabupaten Gunung Mas, 2) kendala yang dihadapi dalam pelayanan kenaikan pangkat pegawai negeri sipil yang diberikan oleh Badan Kepegawaian Daerah Kabupaten Gunung Mas

Adapun manfaat dari penelitian ini adalah 1) memberikan kontribusi pemikiran dan informasi sebagai bahan masukan bagi Pemerintah Daerah Kabupaten Gunung Mas khususnya Badan Kepegawaian Daerah Kabupaten Gunung Mas dalam konsep manajemen kepegawaian, 2) memberikan kontribusi terhadap upaya pengembangan ilmu pengetahuan khususnya pada ilmu administrasi publik terutama masukan mengenai konsep menejemen kepegawaian dalam penyelenggaraan pemerintahan yang baik (Good Governance). 
KAJIAN PUSTAKA

Teori Pelayanan Publik

Keputusan Menteri Negara

Pendayagunaan Aparatur Negara (Meneg PAN)

Nomor 63/KEP/M.PAN/7/2003, memberikan pengertian pelayanan publik yaitu segala kegiatan pelayanan yang dilaksanakan oleh penyelenggara pelayanan publik sebagai upaya pemenuhan kebutuhan penerima pelayanan maupun pelaksana ketentuan peraturan Perundangundangan.

Kemudian dalam kualitas pelayanan, kata kualitas memiliki banyak definisi yang berbeda dan bervariasi dari yang konvensional sampai yang lebih strategik.

Goetsch dan Davis (1994, p. 4) dalam Tjiptono (2000 : 4) membuat definisi mengenai kualitas yang lebih luas cakupannya, definisi tersebut "Kualitas merupakan suatu kondisi dinamis yang berhubungan dengan produk, jasa, manusia, proses, dan lingkungan yang memenuhi atau melebihi harapan".

\section{Indikator Kualitas Pelayanan Publik}

Menurut Gaspersz (1997) dalam Sutopo (2009 : 31), menyatakan bahwa ada beberapa dimensi yang harus diperhatikan dalam meningkatkan kualitas pelayanan, yaitu :

1. Ketepatan waktu pelayanan, hal-hal yang perlu diperhatikan disini terkait dengan waktu tunggu dan waktu proses;

2. Akurasi pelayanan, berkaitan dengan reliabilitas pelayanan dan bebas dari kesalahan pelayanan;

3. Kesopanan dan keramahan dalam memberikan pelayanan, terutama bagi mereka yang berinteraksi dengan pelanggan eksternal seperti operator telepon, petugas keamanan (Satpam), pengemudi, staf administrasi, kasir, petugas penerima tamu, perawat dan lain-lain;

4. Tanggungjawab, berkaitan dengan penerimaan pesanan dan penanganan keluhan dari pelanggan eksternal;

5. Kelengkapan, berkaitan dengan lingkup pelayanan dan ketersediaan sarana pendukung;

6. Kemudahan mendapatkan pelayanan, berkaitan dengan tempat, banyaknya petugas yang melayani, seperti kasir, staf administrasi, fasilits pendukung seperti komputer untuk memproses data dan lainlain ;

7. Atribut pendukung pelayanan lainnya, seperti lingkungan, kebersihan ruang tunggu, ruang tcempat pelayanan, tempat parkir dan ketersediaan informasi.

\section{Faktor-faktor Pelayanan Publik}

Dalam menemukan faktor-faktor yang mempengaruhi pelayanan publik khususnya pelayanan kenaikan pangkat pegawai negeri sipiloleh Badan Kepegawaian Daerah Kabupaten Gunung Mas, penulis mencoba mengacu pada beberapa kerangka teori dan model yang dikembangkan oleh beberapa ahli. Dengan mengacu pada kerangka teori yang digunakan para ahli pada penelitian pelayanan publik. Diharapkan kerangka teori tersebut dapat dijadikan pedoman dalam melihat fenomena yang terjadi dalam pelayanan kenaikan pangkat pegawai negeri sipil oleh Badan Kepegawaian Daerah Kabupaten Gunung Mas, walaupun dalam pelaksanaannya disesuaikan dengan kenyataan dilapangan (actionable causes). 
Menurut Albrecht dan Zemke (1990 : 41) dalam Dwiyanto (2005: 146), kualitas pelayanan publik yang diberikan oleh birokrasi akan dipengaruhi oleh berbagai faktor, seperti tingkat kompetensi aparat, kualitas peralatan yang digunakan untuk memproses pelayanan, dan budaya birokrasi.

\section{Pengertian Pegawai Negeri Sipil}

Dalam Undang-undang Republik Indonesia Nomor 43 Tahun 1999tentang Perubahan atasUndang-undang Nomor 8 Tahun 1974 Tentang Pokok-pokok Kepegawaianyang dimaksud dengan Pegawai Negeri adalah setiap warga negara Republik Indonesia yang telah memenuhi syarat yang ditentukan, diangkat oleh pejabat yang berwenang dan diserahi tugas dalam suatu jabatan negeri, atau diserahi tugas negara lainnya, dan digaji berdasarkan peraturan perundang-undangan yang berlaku.

\section{Sistem Kenaikan Pangkat}

Dalam rangka meningkatkan pelaksanaan pembinaan Pegawai Negeri Sipil atas dasar sistem prestasi kerja dan sistem karir yang dititik beratkan pada sistem prestasi kerja, maka Pegawai Negeri Sipil yang memenuhi syarat dapat dinaikkan pangkatnya. Kenaikan pangkat adalah penghargaan yang diberikan terhadap prestasi kerja dan pengabdian PNS terhadap negara.

\section{Kerangka Fikir}

Kerangka pikir dalam penelitian ini akan menjelaskan mengenai dimensi-dimensi dalamkualitas pelayanan kenaikan pangkat pegawai negeri sipil oleh Badan Kepegawaian Daerah Kabupaten Gunung Mas, yaitu berupa Ketepatan waktu dalam pemberian pelayanan baik itu berupa waktu pengusulan, proses dan penyelesaian, Akurasi dari pelayanan kenaikan pangkat berkaitan dengan reliabilitas pelayanan dan bebas dari kesalahan pelayanan, Kemudahan mendapatkan pelayanan, baik berupa tempat pelayanan, petugas yang melayani/staf administrasi, fasilitas pendukung seperti komputer dan lain-lain. Kemudian kendala-kendala yang dapat menghambat dalam pelayanan kenaikan pangkat pegawai negeri sipil oleh Badan Kepegawaian Daerah Kabupaten Gunung Mas.

\section{METODOLOGI}

Guna menjawab dan mencari pemecahan permasalahan maka penelitian ini menggunakan metode penelitian deskriptif dengan pendekatan kualitatif (Kirk dan Miller dalam Moleong, $1998: 3)$.

Penelitian ini mengambil lokasi pada Badan Kepegawaian Daerah Kabupaten Gunung Mas. Sumber data diperoleh melalui informan, semua kegiatan/aktifitas dan dokumen yang terkait dengan permasalahan yang akan dikaji dibagi dalam dua golongan yaitu data primer (Harbani Pasolong, 2012 : 107) dan data sekunder (Harbani Pasolong, 2012 : 108). Teknik pengumpulan data berupa observasi, wawancara dan dokumentasi.

Karena data dalam penelitian kualitatif banyak menggunakan kata-kata, maka analisis data dilakukan melalui langkah-langkah seperti yang dikemukakan oleh Miles dan Huberman (1994 : 21) yakni, reduksi data, display data dan verifikasi.

Pengujian kredibilitas data penelitian dilakukan dengan cara 1) meningkatkan ketekunan, yaitu melakukan pengamatan secara lebih cermat dan berkesinambungan. Dengan 
cara tersebut maka kepastian data dan urutan peristiwa akan direkam secara pasti dan sistematis, 2) member check (pengecekan anggota), yaitu pengujian kredibilitas data dengan member check, yaitu melakukan diskusi atas hasil penelitian kepada sumber-sumber data yang telah memberikan data. Melalui diskusi ini para narasumber ada yang menyanggah tetapi setelah dijelaskan akhirnya mau memahami, selain itu para narasumber ada yang berinisiatif menambahkan data walaupun ada pula yang menghendaki beberapa data dihilangkan.

\section{HASIL DAN PEMBAHASAN}

\section{Hasil Penelitian}

\section{Pelayanan Kenaikan Pangkat PNS yang} Diberikan oleh BKD Kabupaten Gunung Mas

\section{Ketepatan Waktu}

Salah satu variabel dalam memperoleh kualitas pelayanan yang baik maka yang perlu untuk diperhatikan adalah ketepatan waktu pelayanan yang berkaitan dengan waktu tunggu dan proses. Semakin cepat dan tepat waktu dalam proses pelayanan, maka akan membuat pengguna jasa semakin puas.

Pelaksanaan pelayanan kenaikan pangkat pegawai negeri sipil oleh Badan Kepegawaian Daerah Kabupaten Gunung Mas yang sangat diharapkan oleh pegawai negeri sipil selakupengguna jasa pelayanan kenaikan pangkat yaitu pada aspek penggunaan waktu penyelesaian yang cepat. Dengan semakin cepat pelayanan yang diberikan, maka tingkat kepuasan sebagai pengguna jasa akan tinggi.

\section{Akurasi Pelayanan}

Variabel berikutnya adalah akurasi pelayanan yang berkaitan dengan reliabilitas pelayanan dan apakah pelayanan tersebut bebas dari kesalahan.

Kesalahan dalam kenaikan pangkat pegawai negeri sipil ini dapat terjadi karena kurang telitinya pengguna jasa/pegawai yang mengusulkan kenaikan pangkat dalam melengkapi berkasnya ataupun ketidak telitian petugas pelayanan kenaikan pangkat.

\section{Kemudahan Mendapatkan Pelayanan}

Variabel kemudahan mendapatkan pelayanan yang berkaitan dengan banyaknya outlet/tempat pelayanan, petugas yang melayani/staf administrasi, fasilitas pendukung seperti komputer dan lain-lain.

Fasilitas yang diberikan BKD Kab. Gunung Mas khususnya pada Sub Bidang Mutasi, Pemberhentian dan Pensiun dalam pelayanan kenaikan pangkat pegawai negeri sipil, seperti : Komputer PC 2 Unit, Laptop 1 Unit, papan informasi, leflet.

\section{Kendala dalam Pelayanan Kenaikan Pangkat PNS oleh BKD Kabupaten Gunung Mas}

Pelayanan kenaikan pangkat Pegawai Negeri Sipil oleh Badan Kepegawian Daerah Kabupaten Gunung Mas dalam meningkatkan kualitas pelayanan tentu tidak gampang, ada berbagai kendala yang terjadi baik segi teknis pelayanan dan lain sebagainya.

Kendala-kendala yang kami alami tersebut seperti, kelengkapan berkas usulan kenaikan pangkat yang diajukan oleh pegawai negeri sipil, pada berkas usulan masih sering tidak lengkap padahal Berkas usulan kenaikan pangkat pegawai 
negeri sipil merupakan dokumen-dokumen yang sudah ditetapkan dalam persyaratan kenaikan pangkat, kedua dalam proses penyelesaian yang masih adanya ketidak telitian petugas kami sehingga Surat Keputusan kenaikan pangkat akan menjadi tidak efektif apabila dalam penerbitannya antara data kepegawaian pengguna jasa dengan Surat Keputusan kenaikan pangkat tidak sesuai, ketiga dalam usulan kenaikan pangkat yang diajukan oleh pegawai negeri sipil sering tidak sesuai dengan jadwal yang telah ditetapkan oleh Badan Kepegawaian Daerah Kabupaten Gunung Mas.

\section{Pembahasan}

Pelayanan Kenaikan Pangkat PNS yang Diberikan oleh BKD Kabupaten Gunung Mas

\section{Ketepatan Waktu Pelayanan}

Menurut pendapat Gaspersz (1997) dalam Sutopo (2009 : 31) bahwa dimensi yang harus diperhatikan dalam meningkatkan kualitas pelayanan yaitu ketepatan waktu pelayanan yang berkaitan dengan waktu tunggu dan proses.

Dalam pelayanan kenaikan pangkat pegawai negeri sipil oleh Badan Kepegawaian Daerah Kabupaten Gunung Mas, bahwa harapan pengguna jasa yaitu Pegawai Negeri Sipil khususnya struktural yang naik pangkat pada periode 1 April 2013 tidak semuanya terpenuhi dalam hal ketepatan waktu dalam proses penyelesaian Surat Keputusan kenaikan pangkat karena keterlambatan pada proses penyelesaian SK kenaikan pangkat yang akhirnya menyebabkan proses lainnya seperti penyesuaian gaji menjadi terlambat yang akhirnya menimbulkan ketidakpuasan dari pegawai negeri sipil yang dilayani.

\section{Akurasi Pelayanan}

Kualitas dari suatu pelayanan akan dikatakan baik apabila dari sisi reliabilitasnya yang bagus serta tidak adanya kesalahan. Adanya kesalahan dalam penyelesaian Surat Keputusan yang diterbitkan seperti pada nama, bulan dan tempat tanggal lahir serta ketidak telitian pada pemeriksaan kelengkapan berkas usulan kenaikan pangkat pegawai negeri sipil, hal ini dapat membuat pelayanan menjadi tidak baik karena akan menimbulkan keragu-raguan dari pengguna jasa pelayanan dalam aspek pelayanan bebas dari kesalahan.

$\mathrm{Hal}$ ini relevan dengan pendapat Gaspersz (1997) dalam Sutopo (2009:31) yang menyatakan bahwa akurasi pelayanan seperti reliabilitas pelayanan dan bebas dari kesalahan pelayanan akan berpengaruh terhadap kualitas dari pelayanan.

\section{Kemudahan Mendapatkan Pelayanan}

Bahwa kemudahan mendapatkan pelayanan dalam pengajuan usul kenaikan pangkat sudah bisa dikatakan baik dengan jelasnya tempat ruang pelayanan yang diberikan dan adanya petugas pelayanan yang tanggap dalam menerima usul kenaikan pangkat, tercukupinya fasilitas pendukung seperti komputer untuk memproses data, adanya fasilitas pendukung lain dalam meningkatkan pelayanan seperti adanya leflet sebagai sarana informasi kenaikan pangkat selain informasi persyaratan kenaikan pangkat pada papan informasi serta adanya contact person sebagai upaya memberikan kemudahan kepada pengguna jasa dalam mendapatkan informasi kenaikan pangkat. Hal ini relevan dengan pendapat Gaspersz(1997) dalam Sutopo (2009 : 31) yang menyatakan 
bahwa aspek kemudahan mendapatkan pelayanan juga menentukan kualitas pelayanan yang diberikan kepada pengguna jasa pelayanan yang berkaitan dengan tempat pelayanan, banyaknya petugas yang melayani, seperti kasir, staf administrasi, fasilitas pendukung seperti komputer untuk memproses data dan lain-lain.

\section{Kendala dalam Pelayanan Kenaikan Pangkat PNS oleh BKD Kabupaten Gunung Mas}

Kendala dalam pelayanan kenaikan pangkat pegawai negeri sipil oleh Badan Kepegawaian Daerah Kabupaten Gunung Mas seperti yang telah diuraikan pada hasil penelitian merupakan masalah-masalah yang perlu untuk ditangani karena apa yang menjadi kendala dalam suatu pelayanan akan mempengaruhi kualitas dari pelayanan tersebut.

Dalam penyelenggaraan pelayanan tentunya ada banyak faktor-faktor yang dapat mempengaruhinya sehingga pelayanan menjadi buruk ataupun dapat dikatakan tidak berkualitas, seperti yang disebutkan dalam Surat Keputusan Menteri Pendayagunaan Aparatur Negara (Kep Menpan) Nomor 63/KEP/M.PAN/7/2003 tentang Pedoman Umum Penyelenggaraan Publik.

\section{KESIMPULAN DAN SARAN}

\section{Kesimpulan}

1. Pelayanan kenaikan pangkat Pegawai Negeri Sipil oleh Badan Kepegawaian Daerah Kabupaten Gunung Mas diselenggarakan melalui tahapan. Tahapan dimaksud seperti, Prosedur Pelayanan dan Proses Pelayanan. a. Prosedur pelayanan kenaikan pangkat pegawai negeri sipil oleh Badan Kepegawaian Daerah Kabupaten Gunung Mas telah sesuai dengan Peraturan Pemerintah Nomor 12 tahun 2002 tentang Perubahan Atas Peraturan Pemerintah Nomor 99 tahun 2000 tentang Kenaikan Pangkat Pegawai Negeri Sipil.

b. Proses pelayanan kenaikan pangkat pegawai negeri sipil oleh Badan Kepegawaian Daerah Kabupaten Gunung Mas telah sesuai dengan

Lampiran I Keputusan Kepala Badan Kepegawaian Negara Nomor 12 Tahun 2002 tanggal 17 Juni 2002 tentang Ketentuan pelaksanaan Peraturan Pemerintah Nomor 99 Tahun 2000 tentang Kenaikan Pangkat Pegawai Negeri Sipil sebagaimana telah diubah Dengan Peraturan Pemerintah Nomor 12 Tahun 2002.

2. Pelayanan Kenaikan Pangkat Pegawai Negeri Sipil oleh Badan Kepegawaian Daerah Kabupaten Gunung Mas secara umum baik, hanya masih belum optimal, hal ini terlihat pada aspek Ketepatan Waktu dan Akurasi Pelayanan.

3. Pelayanan kenaikan pangkat pegawai negeri sipil yang diberikan oleh Badan Kepegawaian Daerah Kabupaten Gunung Mas terdapat kendala yang menyebabkan tidak baiknya pelayanan yang diberikan. 


\section{Saran}

1. Lebih meningkatkan lagi rasa tanggungjawab dan konsisten dalam melaksanakan tugas pokok dan fungsi, meningkatkan ketelitian dalam bekerja, dengan demikian kesalahan dalam pelayanan dapat diminimalisir bahkan tidak ada kesalahan lagi dalam pelayanan kenaikan pangkat.

2. Agar memudahkan dalam pengajuan berkas usulan kenaikan pangkat pegawai negeri sipil yang diberikan oleh Badan Kepegawian Daerah Kabupaten Gunung Mas maka dapat menambah lagi loket serta petugas penerima berkas usul kenaikan pangkat serta dapat melakukan roling ruangan dengan ruang lain yang lebih luas sehingga lebih memberikan kenyamanan lagi kepada pengguna jasa dalam pelayanan.

3. Meningkatkan kegiatan sosialisasi yang dapat dilakukan secara bertahap pada tingkat kabupaten, tingkat kecamatan, tingkat kelurahan guna memberikan penjelasanan dalam pengajuan usul kenaikan pangkat sesuai dengan ketentuan yang berlaku.

\section{DAFTAR PUSTAKA}

Azkar, Nurul, dkk, 2010, Pedoman Penulisan Tesis, Pustaka Banua, Banjarmasin

Bratakusumah, Supriady Deddy dan Solihin Dadang, 2004, Otonomi Penyelenggaraan Pemerintahan Daerah, PT. Gramedia Pustaka Utama, Jakarta.

Dwiyanto, Agus, 2005, Mewujudkan Good Governance Melalui Pelayanan Publik, Gadjah Mada University Press, Yogyakarta.

Dwiyanto, Agus, 2006, Mewujudkan Good Governance Melalui Pelayanan Publik, Gadjah Mada University Press, Yogyakarta.
Keputusan Menteri Pendayagunaan Aparatur Negara Nomor 63/KEP/M.PAN/7/2003 tentang Pedoman Umum Penyelenggaraan Pelayanan Publik.

Laporan Akuntabilitas Kinerja Instansi Pemerintah (LAKIP), 2012, Badan Kepegawaian Daerah Kabupaten Gunung Mas.

Lembaga Administrasi Negara Republik Indonesia, 2003, Sistem Administrasi Negara Kesatuan Republik Indonesia.

Peraturan Bupati Gunung Mas Nomor 28 Tahun 2008 tentang Tugas Pokok dan Fungsi Badan Kepegawaian Daerah Kabupaten Gunung Mas.

Peraturan Daerah Kabupaten Gunung Mas Nomor 5 Tahun 2008 tentang Organisasi dan Tata Kerja Inspektorat, Badan Perencana Pembangunan Daerah dan Lembaga Teknis Daerah Kabupaten Gunung Mas, Pemerintah Daerah Kabupaten Gunung Mas, Kuala Kurun.

Peraturan Pemerintah Nomor 8 Tahun 2003 tentang Pedoman Organisasi Perangkat Daerah, Kencana, Jakarta.

Sinambela, Lijan Poltak, dkk, 2006, Reformasi Pelayanan Publik, Teori, Kebijakan, dan Implementasi, Bumi Aksara, Jakarta.

Sutopo, 1999, Pelayanan Prima, Lembaga Administrasi Negara Republik Indonesi, Jakarta.

Sutopo, Suryanto Adi, 2009, Pelayanan Prima, Lembaga Administrasi Negara Republik Indonesi, Jakarta.

Tjiptono, Fandy dan Anastasia Diana, 2000, Total Quality Management, Andi Offset, Yogyakarta.

Undang-undang Dasar Negara Republik Indonesia Tahun 1945.

Undang-undang Nomor 25 Tahun 2009 tentang Pelayanan Publik. 
Undang-undang Nomor 43 Tahun 1999 tentang Perubahan Atas Undang-undang Nomor 8 Tahun 1974 tentang Pokok-pokok Kepegawaian.

Undang-Undang Otonomi Daerah 1999 (UU No. 22 Tahun 1999, UU No. 25 Tahun 1999 dan UU No. 28 Tahun 1999), Kuraiko Pratama, Bandung.

Wahyu. H. 2011. Metode Penelitian Kuantitatif dan Kualitatif, Banjarmasin.

Wajidi. 2009, 10 Juni. Korupsi dalam Sektor Pelayanan Publik, Bubuhan banjar (online) halaman 20. Tersedia : bubuhan banjar.wordpress.com (5 Juni 2013). 